\title{
The Effect of Workload, Leadership Style, And Communication On Employee Work Effectiveness
}

\author{
Didin Hikmah Perkasa ${ }^{1}$ and Harry Martin² \\ ${ }^{1,2}$ Universitas Dian Nusantara \\ Jakarta Indonesia \\ E-mail: didin.hikmah.perkasa@undira.ac.id
}

\section{ABSTRACT}

Indonesia

The main purpose is to determine the relationship among workload, leadership style, and communication on employee work effectiveness used a quantitative descriptive approach. The data in the study were obtained from 55 respondents who were employees of PT. XYZ. Data analysis in this study used an alternative method of structural equation modeling (SEM), namely partial least squares (PLS). The first stage in this research is to test the validity of each variable's questions along with their reliability. The second stage examines the relationship between workload, leadership style, and communication on work effectiveness. The results of this study indicate that the variables of workload, leadership, and communication have a positive and significant effect on work effectiveness.

\section{Keywords: Workload, Leadership Style, Communication, Work Effectiveness}

\section{INTRODUCTION}

The current COVID-19 outbreak worldwide has a considerable impact on all sectors of human life. The World Health Organization(WHO) has designated Coronavirus Disease 2019 or COVID-19 as a pandemic threat. The definition of a pandemic according to the Big Indonesian Dictionary (KBBI) is an epidemic that spreads simultaneously everywhere or covers wide geography. This case began in Wuhan, China, and began to spread to almost all over the world. The spread of COVID-19 is very fast and no one can predict when the COVID-19 pandemic will end.

In the face of a pandemic, the role of leadership and communication is one thing that must be considered so that company performance can be effective, in a review of many research literatures that leadership and communication have a significant effect on work effectiveness (Ichsan,2019); (Sepdwiyana Donargo and Wardayani, 2013); (Sugiarto, 2016). Companies in this case the organization must have employees who are knowledgeable and highly skilled as well as efforts to manage the organization as optimally as possible so that increase the employee effectiveness. In terms of HR needs, it can be calculated by identifying how much the company's output in certain divisions wants to achieve. About the current pandemic, the workload is unavoidable because many employees feel that there is an overload due to the implementation of work from home. The workload is one of the factors that affect the effectiveness of employee work (Nasedum,2019). The workload is a collection or number of activities that must be completed by an organizational unit within a specified time (Suwanto, 2011). The number of tasks and responsibilities given to an employee causes the results achieved to be less than optimal because employees only have little time to complete many tasks. If this happens often, it will have an impact on the effectiveness of the employee's work.

Communication is operationally defined as the exchange of information, both formal and informal between management and employees in the organization. Communication is operationally defined as the technology and systems used to send and receive messages. Communications may include newsletters, circulation materials, surveys, emails, suggestion boxes, etc. Organizational communication focuses on connecting individual employees, groups, and the organization as a whole to facilitate the realization of common interests and spontaneous collaboration.

Based on the results of observations made by researchers that there are problems or phenomena, especially in work effectiveness, errors often occur in shipping goods so that they get complaints from customers. The reasons for this include providing excessive workloads so that targets are not achieved and lack of accuracy in work, this can be seen from the presence of employees who are less thorough and not on time in doing their work and inaccurate time of entry during working hours.

Similar studies related to work effectiveness have been carried out by several previous studies, including research conducted by Dihan, (2013) stated that communication affects work effectiveness. Besides that, Nasedum, (2019) stated that there is an effect of workload on work effectiveness. As well as research conducted by Bahri, (2016) stated that there is an influence of leadership on work effectiveness.

\section{THEORETICAL REVIEW \\ Workload}

Definition of workload by (Suwanto, 2011) is many activities that must be completed by an organizational unit or 


\section{(C) Center for Promoting Education and Research (CPER) USA}

www.cpernet.org

position holder systematically using job analysis techniques, workload analysis techniques or other management techniques within a certain period to obtain information about the efficiency and effectiveness of the work of an organizational unit. According to (Suwanto, 2011) In measuring the workload variable, the following indicators are used: (1) Effective Working Hours; (2) Educational Background; (3) Type of Job Provided.

\section{Leadership Style}

Leadership is an important part of management, but it is not the same as management. Leadership is the ability that a person has to influence other people to work towards achieving goals and objectives. Leadership is the ability that a person has to influence other people to work towards achieving goals and objectives (Handoko, 2012). In a study conducted by Widayati et al., (2017), One of the factors that influence the success or failure of an organization is the leadership style organization. A leader must have the power and authority to govern subordinates to achieve the goals set by the company, so naturally, a leader is required to have more skills and intelligence than his subordinates. The attitude of the leader will determine the development of the team in the company's organization and the developments to be achieved, which in turn will affect the achievement of employee productivity. The ability to develop a team by a leader is the key to the success of the company's activities.

Leadership is a rational and emotional human experience. Leadership includes action and influence based on reason and logic in addition to inspiration and desire (Wirawan,2013). Leadership that can affect work effectiveness is assertive, giving praise, reprimand, appreciation, clarity in giving instructions, orders, supervision, consistent leadership, commitment, and providing appropriate information to individuals or groups to be able to work more effectively and efficiently. Not only work by the rewards but is expected to be able to work beyond what should be done.

Based on the description above, it can be concluded that leadership is the art or ability of a person to influence other people, subordinates, or groups, have special abilities or expertise in the field desired by the group which aims to achieve the desired organizational or group goals.

\section{Communication}

Communication is a very basic and vital social process in human life. It is said to be fundamental because every human society, both primitive and modern, wishes to maintain an agreement on various social rules through communication. In carrying out their work, employees cannot be separated from communication with co-workers, with superiors, and with subordinates. Good communication can be the right means of improving employee performance. Through communication, employees can ask for instructions https://ijbassnet.com/ from their superiors regarding the implementation of work. Through communication, employees can also work together with each other. Communication is a transfer of meaning and understanding of meaning to others.

Organizational communication is a process of exchanging information between individuals through a regular system (common), either with symbols, signals, or behavior or actions (Purwanto,2011). Thus, communication is an effort to build a togetherness that is based on a common perception of something to encourage communication among actors to understand each other by a common desire or goal.

Communication in principle has a relationship by the words above mentioned transfer or delivery or passing of symbols (usually in the form of words) to change the behavior of others. Communication is the process of transferring information, ideas, understanding from one person to another and can interpret it according to the intended purpose (Mangkunegara, 2016).

\section{Effectiveness}

According to Keban, an organization can be said to be effective if the organizational goals or values as set out in the vision are achieved (Pasolong, 2010). Expressing effectiveness relates to the level of truth or success and error, argues that to determine the level of effectiveness of the success of a person, group, organization even to our country, we must make a comparison between truth or accuracy with mistakes or what was done (Prosperous, 2011). The lower the level of errors that occur, of course, the closer the accuracy in the implementation of each activity or work (task) that is charged to each person.

Based on some of the opinions of the experts above, it can be concluded that effectiveness is activities that are directly related to the level of truth or success and error in helping the organization to achieve various goals. The more it reaches the specified target, the better its effectiveness.

\section{The Effect of Workload on Work Effectiveness}

The workload has been measured by conflicts in the workplace, when task demands are low, employees will be able to carry out tasks easily with low workloads and performance remains at optimal levels (Mansoor, Muhammad., Sabtain Fida, 2011). If an error occurs at work, it will cause a cognitive workload or a physical or mental burden. The workload is very important for an organization. By providing an effective workload, the organization can find out to what extent its employees can be given the maximum workload and the extent of its influence on the performance of the organization itself.

Employees often have to complete two or more tasks to be done concurrently. These tasks, of course, require time, effort, and other resources to complete. The burden of 


\section{(C) Center for Promoting Education and Research (CPER) USA}

www.cpernet.org

providing resources that are often limited will certainly cause employee performance to decline. Problems that can arise include weakened employee endurance and feelings of pressure. Feelings of stress make a person irrational, anxious, tense, unable to focus on working and will fail to enjoy joy or satisfaction with the work done. This will prevent someone from realizing positive traits, such as loving work. So, the relationship between the variables is:

H1: Workload has a positive effect on Work Effectiveness.

\section{The Effect of Leadership Style on Work Effectiveness}

Leadership is an organizational locomotive that is always interesting to talk about. This attraction is based on a historical background that shows the importance of the existence of a leader in each group activity and the fact that leadership is the center of the pattern of interaction between organizational components. Leadership is a relationship that exists within a leader, influencing others to cooperate consciously in the desired task relationship (Raharjo, 2013). Leadership is indispensable for an organization in determining the progress and setbacks of the organization, good leadership will achieve work effectiveness (Ichsan, 2019); (Manalu, 2012). From the opinion of experts and previous studies, it can be concluded that there is a strong relationship and effect between leadership style and work effectiveness. So, the relationship between the variables is: H2: Leadership Style has a positive effect on Work Effectiveness

\section{The Effect of Communication on Work Effectiveness}

According to some experts, they have an opinion about what "communication" is. Communication is the transfer of process something information, ideas, understanding from one person to another can interpret according to the intended purpose (Mangkunegara,2016). The efforts made by employees in handling their work have a direct effect on realizing the results of the company's work. The role of the individual in the company overall very important. Therefore, communication and morale are very important to achieve company goals effectively and efficiently. The thing that must be considered by the leadership is the need for communication with employees so that they are more active at work. Proper communication will encourage employees to be more interested and enthusiastic about work. This will indirectly have an impact on tasks that are carried out properly and responsibly.

Communication is a basic human activity. The importance of communication is not limited to personal communication but also organizational communication. Lack or absence of communication within an organization can result in the smooth running of the organization's activities itself. Thus, communication in every organization has a central role in the process, and a pattern of communication is a necessary means to coordinate and direct the activities of employees to the goals and objectives of the organization (Sepdwiyana Donargo and Wardayani, 2013); (Sugiarto, 2016). It can be concluded that there is a strong relationship and effect between Communication and Work Effectiveness. So, the relationship between the variables is:

H3: Communication has a positive effect on Work Effectiveness RESEARCH METHODS

\section{Research design}

The research design used by the researcher in this research is causal research. Causal is a causal relationship where the independent variable affects the dependent variable (Sugiyono, 2014). This study aims to test the hypothesis about the effect of one or several variables on other variables with statistical tests. Where this study aims to determine the effect of Workload (X1), Leadership Style (X2), and Communication (X3) on Work Effectiveness (Y) at PT. XYZ.

\section{Population and Research Sample}

The population is a generalization area consisting of objects or subjects that have certain qualities and characteristics determined by the researcher to be studied and then draw conclusions (Sugiyono, 2014). The population is not only humans but can also be objects or objects of the subject being studied such as documents that can be considered as objects of research. The population is also not just the number of objects/subjects studied but includes all the characteristics/properties possessed by the subject or object. Based on the research place that has been determined, the population that is used as the object of the research is the employees of PT. XYZ, with a total of 55 respondents.

The sample is part of the number and characteristics possessed by the population, for that samples taken from the population must be truly representative (Sugiyono, 2014). By using saturated sampling as a sampling technique. Saturated sampling is a sampling technique where all members of the population are used as samples. This is often done when the population is relatively small, at least less than 30 people, or research that wants to make generalizations with very small errors (Sugiyono, 2014). The saturated sample is also often interpreted as the maximum sample, plus any amount will not change the representativeness. With a limited population of 55, the number of samples, i.e. all the population is used as a sample that is 55 respondents who are used as samples. 


\section{RESULTS AND DISCUSSION Convergent Validity}

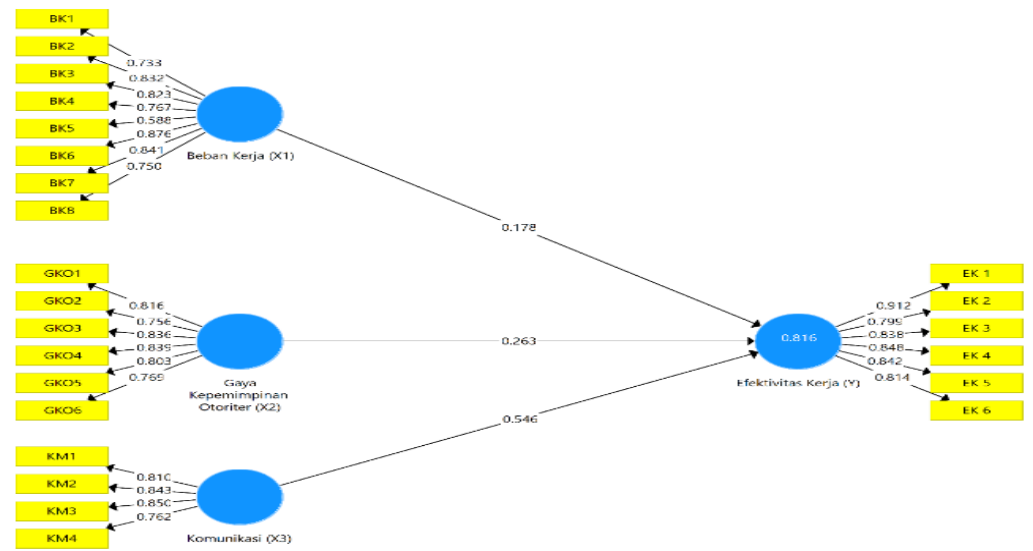

Figure 1. Results of the PLS Algorithm

Source: 2021 PLS Output

Table 1. Convergent Validity Test Results

\begin{tabular}{|c|c|c|c|}
\hline Variable & Indicator & Outer Loading & Conclusion \\
\hline \multirow[t]{8}{*}{ Workload } & BK1 & 0.733 & Valid \\
\hline & BK2 & 0.832 & Valid \\
\hline & BK3 & 0.823 & Valid \\
\hline & BK4 & 0.767 & Valid \\
\hline & BK5 & 0.588 & Invalid \\
\hline & BK6 & 0.876 & Valid \\
\hline & BK7 & 0.841 & Valid \\
\hline & BK8 & 0.750 & Valid \\
\hline \multirow[t]{6}{*}{ Authoritarian Leadership Style } & GKO1 & 0.816 & Valid \\
\hline & GKO2 & 0.756 & Valid \\
\hline & GKO3 & 0.836 & Valid \\
\hline & GKO4 & 0.839 & Valid \\
\hline & GKO5 & 0.803 & Valid \\
\hline & GKO6 & 0.769 & Valid \\
\hline \multirow[t]{4}{*}{ Communication } & KM1 & 0.810 & Valid \\
\hline & KM2 & 0.843 & Valid \\
\hline & KM3 & 0.850 & Valid \\
\hline & KM4 & 0.762 & Valid \\
\hline \multirow[t]{6}{*}{ Work Effectiveness } & EK 1 & 0.912 & Valid \\
\hline & EK 2 & 0.799 & Valid \\
\hline & EK 3 & 0.838 & Valid \\
\hline & EK 4 & 0.848 & Valid \\
\hline & EK 5 & 0.842 & Valid \\
\hline & EK 6 & 0.814 & Valid \\
\hline
\end{tabular}

Source: Processed primary data (2021)

Based on Figure 1 and Table 1, it can be seen that the description above, the statements of each invalid variable there are several invalid statements, namely the statement will be dropped from the model. BK5 (0.588) with a loading factor value below 0.6. Based on

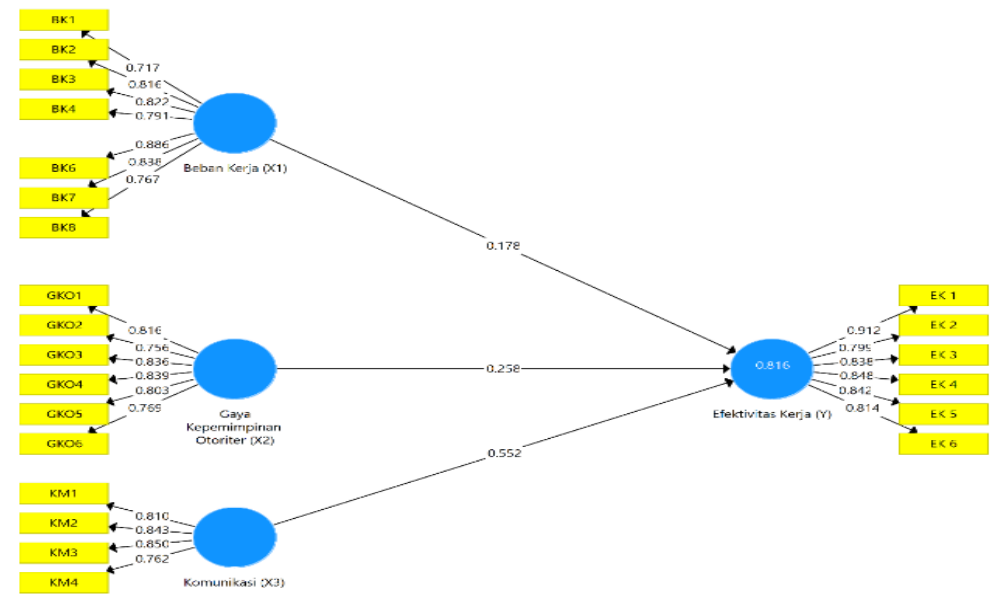

Figure 2. Results of the PLS Algorithm (Modification 1)

Source: 2021 PLS Output 
Table 2. Convergent Validity (Modification 1)

\begin{tabular}{lccc}
\hline Variable & Indicator & Outer Loading & Conclusion \\
\hline Workload & BK1 & 0.717 & Valid \\
& BK2 & 0.816 & Valid \\
& BK3 & 0.822 & Valid \\
& BK4 & 0.791 & Valid \\
& BK6 & 0.886 & Valid \\
& BK7 & 0.838 & Valid \\
Authoritarian Leadership Style & BK8 & 0.767 & Valid \\
& GKO1 & 0.816 & Valid \\
& GKO2 & 0.756 & Valid \\
& GKO3 & 0.836 & Valid \\
& GKO4 & 0.839 & Valid \\
Communication & GKO5 & 0.803 & Valid \\
& GKO6 & 0.769 & Valid \\
& KM1 & 0.810 & Valid \\
KM2 & 0.843 & Valid \\
& KM3 & 0.850 & Valid \\
& KM4 & 0.762 & Valid \\
& EK 1 & 0.912 & Valid \\
& EK 2 & 0.799 & Valid \\
& EK 3 & 0.838 & Valid \\
& EK 4 & 0.848 & Valid \\
& EK 5 & 0.842 & Valid \\
\hline Source: Processed primary data (2021) & & 0.814 & Valid
\end{tabular}

Based on Figure 2 and Table 2, it can be seen that all convergent validity can also be assessed by looking at the questions have met the outer loadings criteria, namely $>0.6$. average variance extracted (AVE) value. In addition to looking at the value of loading factors,

Table 3. Convergent Validity (AVE) Test Results

\begin{tabular}{lcc}
\hline Construct & Average Variance Extracted (AVE) & Information \\
\hline BK $(\mathrm{X} 1)$ & 0.651 & Valid \\
GKO $(\mathrm{X} 2)$ & 0.646 & Valid \\
KO $(\mathrm{X} 3)$ & 0.668 & Valid \\
EK $(\mathrm{Y})$ & 0.711 & Valid \\
\hline
\end{tabular}

Source: Output processing with SmartPLS 3 (2021)

From the results of the convergent validity construct discriminant validity which is carried out by looking at the test in the table above, it can be seen that each construct has square root of average variance extracted (AVE) value for met the criteria with an average variance extracted (AVE) each construct with the correlation value among constructs in value above 0.50 .

\section{a. Discriminant Validity}

the model. This method is often called the Fornell Larcker

Since there is no problem with convergent validity, the next step to be tested is the problem related to

\section{Table 4. Fornell Larcker Criterion . Test Results}

\begin{tabular}{lcccc}
\hline & $(\mathrm{X} 1)$ & $(\mathrm{Y})$ & $(\mathrm{X} 2)$ & $(\mathrm{X} 3)$ \\
\hline BK $(\mathrm{X} 1)$ & 0.807 & & & \\
EK $(\mathrm{Y})$ & 0.655 & 0.843 & & \\
GKO $(\mathrm{X} 2)$ & 0.486 & 0.818 & 0.804 & \\
KO $(\mathrm{X} 3)$ & 0.638 & 0.886 & 0.858 & 0.817 \\
\hline \multicolumn{5}{c}{ Source: 2021 PLS Output }
\end{tabular}

Viewed from Table 4, it can be seen that the square validity. So it is necessary to modify the indicators that have root of the average variance extracted is $0.807,0.843,0.804$, the lowest values (GKO2 and KM4) on the variables that and 0.817 . These values are smaller than the correlation of occur lack of values shown in the figure and structural table each construct and do not meet the criteria for discriminant below: 


\section{E-ISSN: $2469-6501$ \\ VOL: 7, ISSUE: 6 \\ June/2021 \\ http://dx.doi.org/10.33642/ijbass.v7n6p6}

CPER

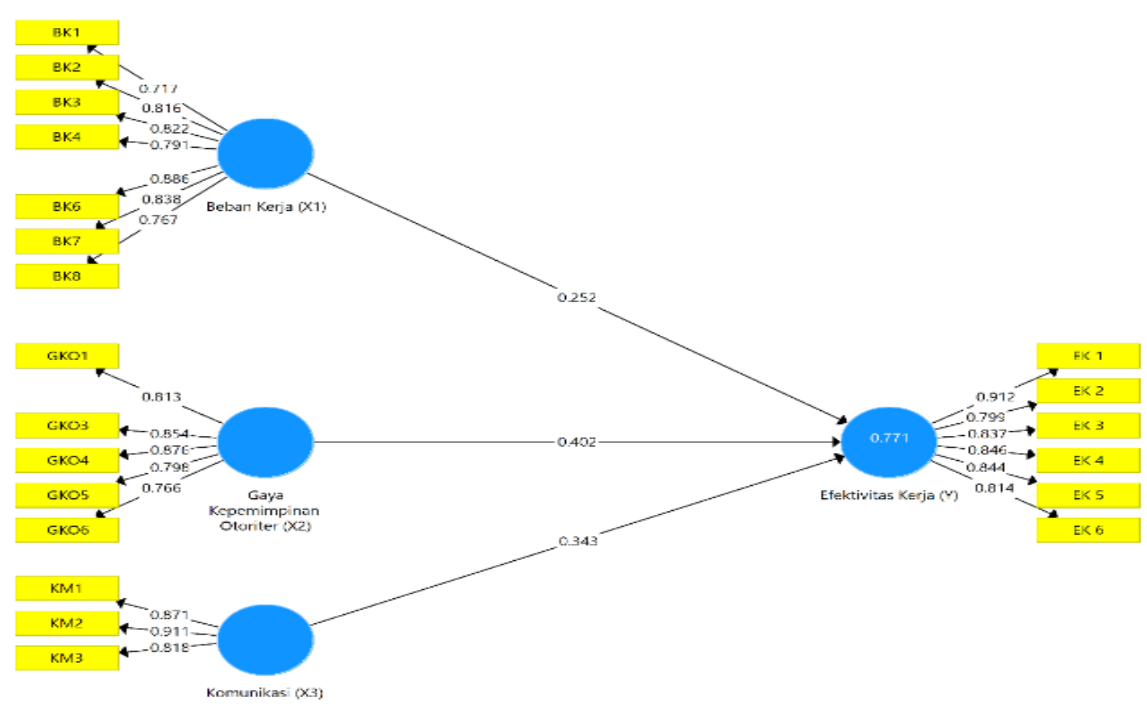

Figure 3. Results of the PLS Algorithm (Modification 2)

Source: 2021 PLS Output

Table 5. Convergent Validity Test-Modification 2

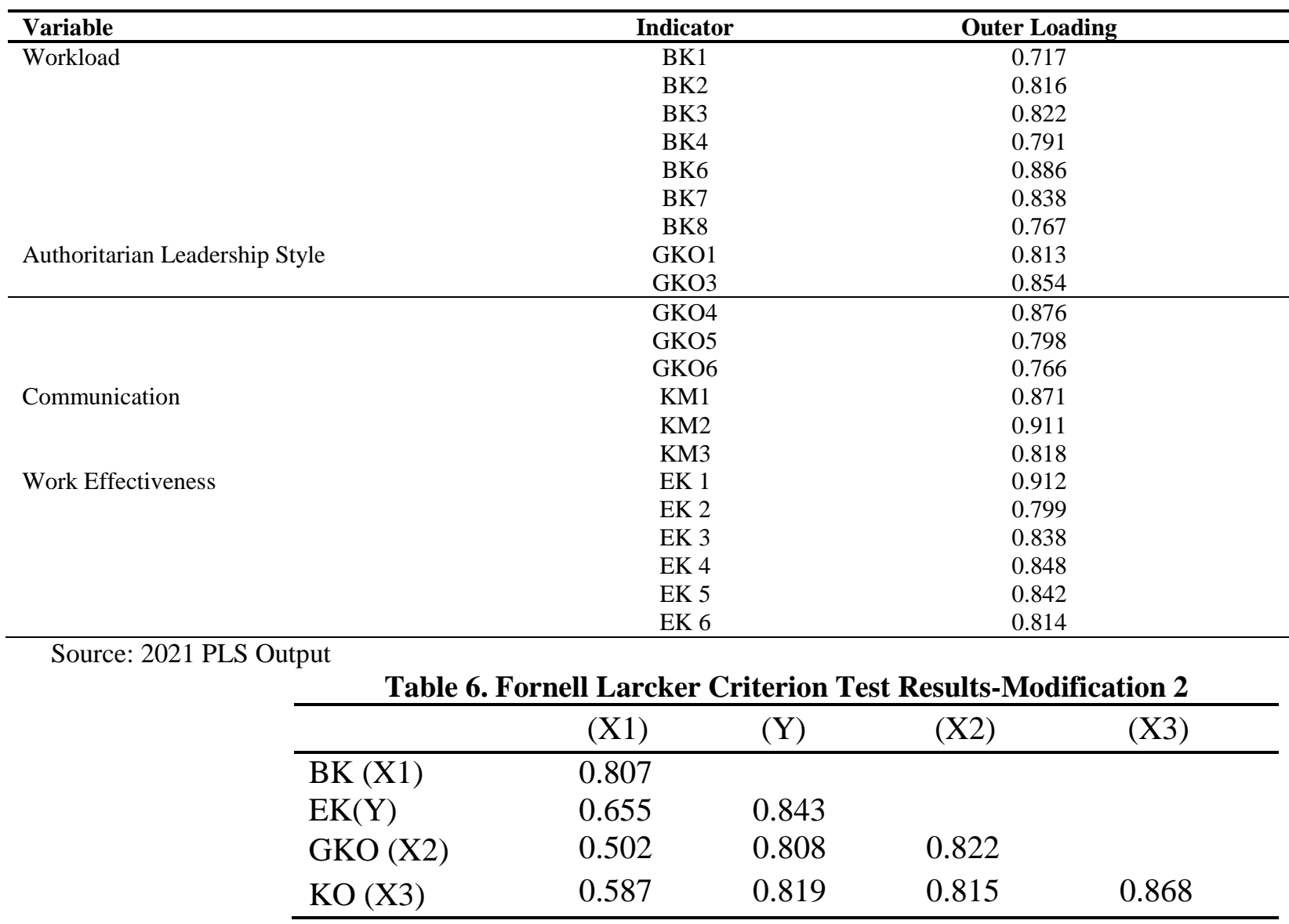

Source: 2021 PLS Output

From Table 6 it can be seen that the square root However, the average variance extracted (AVE) value in the values of average variance extracted are $0.807,0.843,0.822$, convergent validity test also changed along with the removal and 0.868 . These values are greater than the correlation of of two indicators from the construct.

each construct and meet the criteria of discriminant validity. 
E-ISSN: 2469-6501

VOL: 7, ISSUE: 6

June/2021

http://dx.doi.org/10.33642/ijbass.v7n6p6

Table 7. Convergent Validity (AVE) Test Results

\begin{tabular}{lcc}
\hline Construct & Average Variance Extracted (AVE) & Information \\
\hline BK $(\mathrm{X} 1)$ & 0.651 & Valid \\
GKO $(\mathrm{X} 2)$ & 0.676 & Valid \\
KO $(\mathrm{X} 3)$ & 0.753 & Valid \\
EK $(\mathrm{Y})$ & 0.711 & Valid \\
\hline
\end{tabular}

Source: Output processing with SmartPLS 3 (2021)

From the results of the convergent validity construct test in the table above, it can be seen that each construct has met the criteria with an average variance extracted (AVE) value above 0.50 . Another method to see discriminatory validity is to use reflexive indicators, namely by looking at the cross-loading value for each variable that must be $>0.70$
(Ghozali 2015). An indicator is declared valid if it has the highest loading factor for the intended construct compared to the loading factor for other constructs. Thus, latent constructs predict indicators in their block better than indicators in other blocks.

Table 8. Discriminant Validity Test Results (Cross Loading)

\begin{tabular}{lcccc}
\hline & $\mathbf{X 1}$ & $(\mathbf{Y})$ & $(\mathbf{X 2})$ & $(\mathbf{X 3 )}$ \\
\hline BK1 & $\mathbf{0 . 7 1 7}$ & 0.445 & 0.303 & 0.321 \\
BK2 & $\mathbf{0 . 8 1 6}$ & 0.454 & 0.285 & 0.365 \\
BK3 & $\mathbf{0 . 8 2 2}$ & 0.517 & 0.346 & 0.439 \\
BK4 & $\mathbf{0 . 7 9 1}$ & 0.652 & 0.547 & 0.528 \\
BK6 & $\mathbf{0 . 8 8 6}$ & 0.533 & 0.406 & 0.513 \\
BK7 & $\mathbf{0 . 8 3 8}$ & 0.491 & 0.379 & 0.536 \\
BK8 & $\mathbf{0 . 7 6 7}$ & 0.551 & 0.495 & 0.557 \\
EK 1 & 0.582 & $\mathbf{0 . 9 1 2}$ & 0.790 & 0.806 \\
EK 2 & 0.549 & $\mathbf{0 . 7 9 9}$ & 0.674 & 0.627 \\
EK 3 & 0.481 & $\mathbf{0 . 8 3 7}$ & 0.696 & 0.618 \\
EK 4 & 0.575 & $\mathbf{0 . 8 4 6}$ & 0.635 & 0.786 \\
\hline EK 5 & 0.562 & $\mathbf{0 . 8 4 4}$ & 0.633 & 0.651 \\
EK 6 & 0.563 & $\mathbf{0 . 8 1 4}$ & $\mathbf{0 . 8 1 3}$ & 0.623 \\
GKO1 & 0.698 & $\mathbf{0 . 8 5 4}$ & 0.731 \\
GKO3 & 0.477 & 0.745 & $\mathbf{0 . 8 7 6}$ & 0.701 \\
GKO4 & 0.465 & 0.648 & $\mathbf{0 . 7 9 8}$ & 0.617 \\
GKO5 & 0.391 & 0.572 & $\mathbf{0 . 7 6 6}$ & 0.641 \\
GKO6 & 0.275 & 0.6348 & 0.650 \\
KM1 & 0.428 & 0.725 & 0.720 & $\mathbf{0 . 8 7 1}$ \\
KM2 & 0.438 & 0.676 & 0.650 & $\mathbf{0 . 9 1 1}$ \\
KM3 & 0.445 & 0.723 & & $\mathbf{0 . 8 1 8}$ \\
\hline
\end{tabular}

Source: 2021 PLS Output

From Table 8, it can be concluded that the loading value of each of the intended constructs is greater than the loading value of the other constructs. It can be concluded that all existing indicators are valid and there are no problems with discriminant validity.

\section{b. Composite Reliability and Cronbach's Alpha}

The reliability test was carried out used Composite Reliability and Cronbach's Alpha tests by looking at all values of latent variables having Composite Reliability and Cronbach's Alpha values 0.7, it means that the construct has good reliability or the questionnaire used as a tool in this study is reliable or consistent. The test results are presented in the following table:

Table 9. Composite Reliability Test Results

\begin{tabular}{lccl}
\hline Variable & Composite Reliability & Cronbach Alpha & Information \\
\hline BK $(X 1)$ & 0.929 & 0.910 & Reliable \\
GKO $($ X2) & 0.912 & 0.880 & Reliable \\
KO $(X 3)$ & 0.901 & 0.835 & Reliable \\
EK $(Y)$ & 0.936 & 0.918 & Reliable \\
\hline
\end{tabular}


Based on Table 9, it can be seen that the results of the Composite Reliability test show that all latent variable values have a Composite Reliability value of 0.7. And the results of the Cronbach's Alpha test also show that all values of the latent variables have a Cronbach's Alpha value of 0.7 so it can be concluded that the construct has good reliability or the questionnaire used as a tool in this research is reliable or consistent.

\section{Structural Model Testing/Hypothesis Testing (Inner Model)}

After the estimated model meets the Outer Model criteria, the next step is to test the structural model (Inner model). The evaluation of the structural model (Inner model) aims to predict the relationship between latent variables which can be seen from the value of the coefficient of determination (R2), as well as predictive relevance (Q2) to assess the structural (inner model) (Ghozali 2015).

\section{a. R-Square Value}

Coefficient determination R-square (R2) showed how much the exogenous variable explains the endogenous variable. The value of R-square (R2) is zero to one. If the value of R-Square (R2) is getting closer to one, then the independent variables provide all the information needed to predict the variation of endogenous variables. On the other hand, the smaller the value of R-Square (R2), the more limited the ability of the independent variables in explaining the variation of endogenous variables. The value of $\mathrm{R}$-square (R2) has a weakness, namely the value of R-Square (R2) will increase every time there is an addition of one exogenous variable even though the exogenous variable has no significant effect on the endogenous variable.

The value of R-square (R2) or the coefficient of determination of the work effectiveness construct was 0.711 . These results indicate that the endogenous variables of work effectiveness can be explained by exogenous variables, namely workload, authoritarian leadership style, and communication by $71 \%$ while the remaining $29 \%$ was explained by other exogenous variables.

\section{b. Predictive Relevance Value (Q Square)}

Predictive relevance(Q2) for the structural model measures how well the observed values are generated. Predictive Relevance (Q2) for the structural model measures how well the observed values are generated by the model and also the estimated parameters. Applies only to contemplating endogenous factor models. Predictive Relevance (Q2) is greater than 0. Similarly, a Predictive Relevance (Q2) with 0 or negative values indicates the model is not relevant to a given endogenous factor prediction. Based on the calculation of predictive relevance $(\mathrm{Q} 2)$ in table 4.17 which shows a value of 0.503 , it can be concluded that the model has a relevant predictive value.

\section{c. Goodness of Fit Model (GoF)}

The Goodness of Fit Model (GoF) describes the overall level of fit of the model which is calculated from the squared residual of the predicted model compared to the actual data introduced by Tenenhaus et al. (2004). This GoF index is a single measure used to validate the combined performance of the measurement model (outer model) and structural model (inner model). The value of the Goodness of Fit Model (GoF) index is obtained from the Verage communalities index multiplied by the $\mathrm{R} 2$ value of the model. GoF values range from 0-1 with the following interpretation:

Goodness of Fit (GoF) Small GoF $=0.1$

Goodness of Fit $(\mathrm{GoF})$ Moderate or Moderate $=0.25$

Goodness of Fit (GoF) Large $=0.38$

Goodness of Fit (GoF) formula:

$$
\begin{aligned}
& \text { GoF }=\sqrt{\overline{\overline{A V E} \times \overline{R^{2}}}} \\
& =\sqrt{0.651 \times 0.711} \\
& =0.680
\end{aligned}
$$

From the calculation of Goodness of Fit (GoF) above, it can be seen that the result is 0.680 , from these results it can be concluded that the performance between the measurement model and the structural model has a large GoF of 0.680 (above 0.38). This means that $68 \%$ of the variation in work effectiveness variable is explained by the variables used.

\section{Hypothesis Testing Results (Estimated Path Coefficient)}

This hypothesis testing stage was carried out after the structural model evaluation stage has been done. This stage was carried out to determine whether the research hypothesis proposed in the research model was accepted or rejected. To test the proposed hypothesis, it can be seen from the original sample and the T-Statistic value through the bootstrapping procedure.

\section{Table 10. Hypothesis Testing Results}

\begin{tabular}{ccccccc}
\hline Hypothesis & Path & $\begin{array}{c}\text { Original } \\
\text { Sample } \\
(\mathrm{O})\end{array}$ & $\begin{array}{c}\text { Sample } \\
\text { Mean } \\
(\mathrm{M})\end{array}$ & $\begin{array}{c}\text { Standard } \\
\text { Deviation } \\
(\text { STDEV })\end{array}$ & $\begin{array}{c}\text { T-Statistic } \\
(|\mathrm{O} / \mathrm{STDEV}|)\end{array}$ & P-Values \\
\hline H1 & $\mathrm{BK}>\mathrm{EK}$ & 0.252 & 0.260 & 0.086 & 2,947 & 0.003 \\
$\mathrm{H} 2$ & $\mathrm{GKO}>\mathrm{EK}$ & 0.402 & 0.389 & 0.120 & 3.355 & 0.001 \\
$\mathrm{H} 3$ & $\mathrm{LJ}>\mathrm{EK}$ & 0.343 & 0.353 & 0.154 & 2.228 & 0.026 \\
\hline
\end{tabular}


E-ISSN: 2469-6501

VOL: 7, ISSUE: 6

June/2021

http://dx.doi.org/10.33642/ijbass.v7n6p6

\section{(C) Center for Promoting Education and Research (CPER) USA}

WwW.cpernet.org

Based on Table 10, it can be seen that the workload has a positive and significant effect on work effectiveness. This is indicated by the test results between the two variables which showed that the original sample value of 0.252 which is close to the value of +1 and has a T-Statistic value of 2,947 (>1.96). Meanwhile, based on Table 10, it can be seen that the authoritarian leadership style has a positive and significant effect on work effectiveness. This is indicated by the test results between the two variables which show the original sample value of 0.402 which is close to the value of +1 and has a T-Statistic value of 3.335 (> 1.96).

In addition, based on Table 10, it can be seen that communication has a positive and significant effect on work effectiveness. This is indicated by the test results between the two variables which show the original sample value of 0.343 which is close to +1 and has a T-Statistic value of 2.228 (> 1.96).

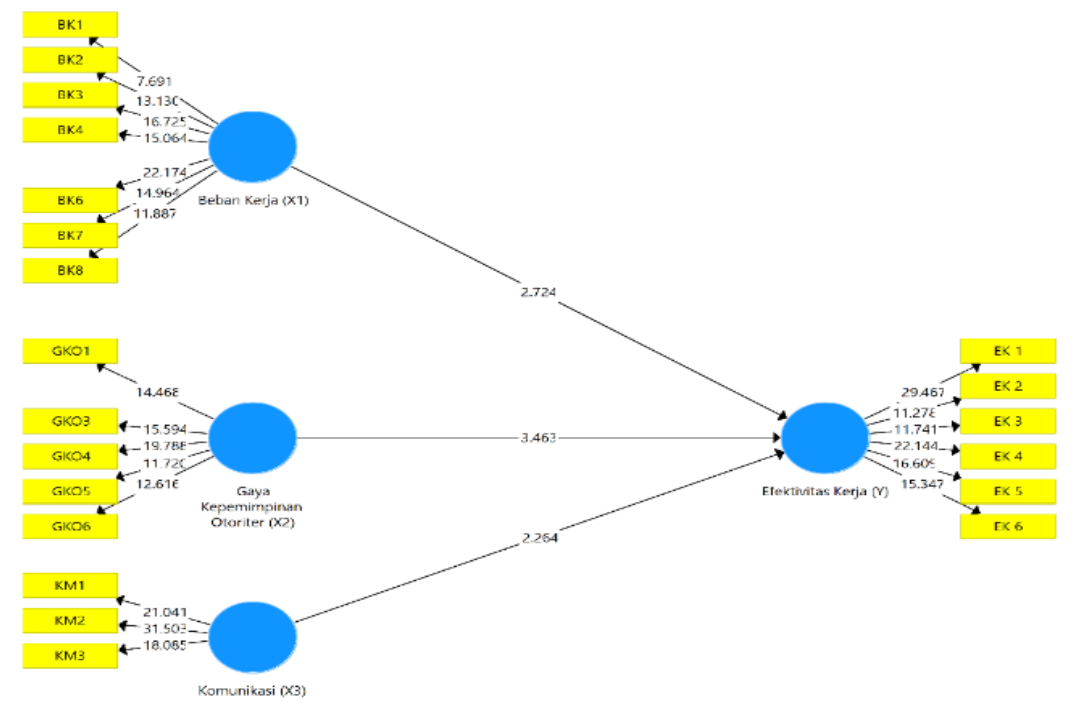

Figure 4. Bootstrapping of Test Results

Source: 2021 PLS Output

\section{Discussion}

This study aims to determine the effect of workload, authoritarian leadership style, and work communication on work effectiveness at PT. XYZ. Exogenous variables assessed in this research model are workload, authoritarian leadership style, and work communication. While the endogenous variable assessed in this research model is work effectiveness.

\section{The effect of workload on work effectiveness}

Based on the test results on the effect of workload on work effectiveness, the original sample value is 0.252 which is close to the value of +1 and has a T-Statistic value of 2,947 (>1.96) so it can be concluded that the first hypothesis (H1) is accepted and the workload has a positive and significant effect on work effectiveness. The results of this study strengthen the previous research (Nasedum, 2019); (Prihatin, 2008); (Paramitadewi Ferrania, 2017) which proves that the workload has a positive and significant effect on work effectiveness.

2.The effect of authoritarian leadership style on work effectiveness

Based on the test results on the effect of authoritarian leadership style on work effectiveness, the original sample value is 0.402 which is close to the value of +1 and has a T-
Statistic value of $3.335(<1.96)$ so it can be concluded that the second hypothesis (H2) is accepted and the authoritarian leadership style has a positive and significant effect on work effectiveness. The results of this study strengthen the previous research (Sepdwiyana Donargo and Wardayani, 2013); (Ichsan, 2019); (Sugiarto, 2016); (Bahri, 2016) which proves that leadership style has a positive and significant effect on work effectiveness.

\section{The effect of communication on work effectiveness}

Based on the test results on the effect of communication on work effectiveness, the original sample value is 0.343 which is close to +1 and has a T-Statistic value of 2.228 (> 1.96) so it can be concluded that the third hypothesis (H3) is accepted and communication has a positive and significant effect on work effectiveness. The results of this study strengthen the previous research, (Sepdwiyana Donargo and Wardayani, 2013); (Ichsan, 2019); (Sugiarto, 2016), which proves that communication has a positive effect on work effectiveness.

\section{CONCLUSION}

Based on the results of the hypothesis test and discussion above, several conclusions can be drawn as follows: 


\section{International Journal of Business and Applied Social Science (IJBASS)}

E-ISSN: 2469-6501

VOL: 7, ISSUE: 6

June/2021

http://dx.doi.org/10.33642/ijbass.v7n6p6

1. Workload has a positive and significant effect on work effectiveness at PT. XYZ Tanah Abang Branch. This proves that the workload factor that has a direct role in encouraging work effectiveness at PT. XYZ Tanah Abang Branch.

2. Authoritarian leadership style has a positive and significant effect on work effectiveness at PT. XYZ Tanah Abang Branch. This proves that the leadership style factor has a direct role to encourage work effectiveness at PT. XYZ Tanah Abang Branch.

3. Communication has a positive and significant effect on work effectiveness at PT. XYZ Tanah Abang Branch. This proves that the communication factor has a direct role in encouraging work effectiveness at PT. XYZ Tanah Abang Branch.

\section{REFERENCES}

Bahri, M. S. (2016). Analisis Pengaruh Gaya Kepemimpinan dan Disiplin Kerja Terhadap Efektivitas Kerja Guru di SMK Hidayatul Islam Clarak Kecamatan Leces Kabupaten Probolinggo. Penelitian Ilmu Ekonomi WIGA, 6(2), 2.

Feresthi Nurdiana DIhan. (2013). Pengaruh Kepemimpinan, Budaya Organisasi, Dan Komunikasi Kerja Terhadap Efektivitas

Kerja : Kasus Wanita Pekerja di Sektor Perbankan. 4(1), 62-75.

Handoko, T. H. (2012). Manajemen personalia dan sumber daya manusia. Yogyakarta: BPFE.

Ichsan, R. N. (2019). KEPEMIMPINAN, KOMUNIKASI DAN EFEKTIVITAS KERJA PEGAWAI PEMERINTAH KOTA

LHOKSEUMAWE. Jurnal Manajemen Tools, 8(5), 55.

Makmur. (2011). Efektivitas Kebijakan Kelembagaan Pengawasan. Bandung: Refika Aditama.

Manalu. (2012). Pengaruh Kepemimpinan, Motivasi Dan Kreativitas Terhadap Efektivitas Kinerja Dosen Di Universitas Dharma Agung Medan. 1(1).

Mangkunegara, A. (2016). Manajemen Sumber Daya Manusia. PT. Remaja Rosdakarya Bandung.

Mansoor, Muhammad., Sabtain Fida, D. (2011). The ImpactiofiJob Stres on EmployeeJob Satisfaction A study on

Telecommunication Sector of Pakistan. Journal of Business Studies Quarterly, 2(3), 50-56.

Nasedum, I. R. (2019). Hubungan Beban Kerja dan Pelatihan Terhadap Efektivitas Kerja Perawat Dalam Pelaksanaan Asuhan

Keperawatan Di Ruang Rawat Inap BLUD RSU Sele Be Solu Kota Sorong. Jurnal Inovasi Kesehatan, 1(Oktober), 2630.

Paramitadewi Ferrania, K. (2017). Pengaruh Beban Kerja dan Kompensasi terhadap Kinerja Pegawai Sekretariat Pemerintah

Daerah Kabupaten Tabanan. E-Jurnal Manajemen Universitas Udayana, 6(6), 255108.

Pasolong. (2010). Teori Administrasi Publik. Alfabeta, Bandung.

Prihatin, F. Dan W. (2008). Analysis of Use of Work Time and Work Loads On the Effectiveness of Work with Work Satisfaction

As an Intervening Variable in Pt Visionland Karangjati Semarang District. Universitas Padanaran Semarang, 1(1), 1-15.

Purwanto. (2011). Evaluasi Hasil Belajar. Yogyakarta: Pustaka Pelajar.

Raharjo, H. U. dan N. E. (2013). Strategi Kepemimpinan Pembelajaran Menyongsong Implementasi Kurikulum. 1-13.

Sepdwiyana Donargo dan Wardayani. (2013). Pengaruh Komunikasi Interoersonal dan Gaya Kepemimpinan Terhadap Efektivitas

Kerja Karyawan Pada Politeknik Pariwisata Medan. Journal of Chemical Information and Modeling, 53(9), 1689-1699.

Sugiarto, C. (2016). Analisis Pengaruh Gaya Kepemimpinan, Komunikasi Internal, Budaya Organisasi Dan Disiplin Kerja

Terhadap Efektivitas Kerja Karyawan Koperasi Agrobisnis Tarutama Nusantara (Kopa Ttn) Jember. Bisma Jurnal Bisnis

Dan Manajemen, 10(3), 240-251.

Sugiyono. (2014). Metode Penelitian Pendidikan Pendekatan Kuantitatif,Kualitatif Dan R\&D. Alfabeta.

Suwanto. (2011). Pengaruh Mutasi Kerja, Beban Kerj, Dan Konflik Interpersonal Terhadap Stress Kerja Serta Dampaknya Pada

Efektifitas Pegawai Bpkp Perwakilan Provinsi Aceh.

Widayati, C., Rahardjo, T. H., \& Febriyanti, M. (2017). Pengaruh Gaya Kepemimpinan Transformasional, Motivasi Dan

Kompensasi Terhadap Kinerja Karyawan. Jurnal Ekonomi, 22(3).

Wirawan. (2013). Kepemimpinan: Teori, psikologi, perilaku organisasi, aplikasidan penelitian. Jakarta: Rajawali Pers. 